REFERENCES

Board of Education (1941). Circ. Bd Educ. no. $157 \mathrm{I}$

Great Britain Parliament (I906). Education (Provision of Meals) Act 1906. London: H.M. Stationery Office.

Great Britain Parliament (Igr4). Education (Provision of Meals) Act 1914. London: H.M. Stationery Office.

Great Britain Parliament (1944). Education Act 1944. London: H.M. Stationery Office.

Ministry of Education (1955). Circ. Minist. Educ. no. 290. London: H.M. Stationery Office.

\title{
Appetites in retirement: the organized feeding of old people
}

\author{
By Denrse W. Newman (Honorary Organizing Secretary, Surrey Old People's \\ Welfare Committee), Little Tangley, Wealdway, Caterham, Surrey
}

At the end of a day of papers covering almost the Seven Ages of Man it is fitting that the last of them should deal with the problem of feeding elderly people. Fortunately I am not called upon to give a scientific treatise on the part played by nutrition in the ageing processes because our knowledge is lamentably small. It is, however, as important to assess the effect of growing old, with all its implications, on the individual's attitude to feeding, which can be done a little more readily.

The feeding of old people has not hitherto been a community responsibility as a specialized activity. The old Poor Law Institutions were the only places where the aged would be found in any numbers, and here they were accorded no separate consideration but were fed in the same way and by the same standards as any other inmates. Tojudge by the figures in the late Professor Drummond's book The Englishman's Food, recently revised by Dorothy Hollingsworth (Drummond \& Wilbraham, I957), they were not so badly off nutritionally even if their dietary regime owed little to inspiration. However, in view of the present-day population trends which give an estimated figure for the 1980's of one person in five being over pensionable age, the subject of this paper is timely.

If we compare this section of the community with others considered in this Symposium a major characteristic emerges. This group is relatively static. The child grows and learns, the hospital patient in the main recovers, the factory and service groups present an age range, but the old merely get older with an aggravation of those difficulties inherent in the condition. I am defining here, of course, those old people who are having to exhibit some degree of dependance on community help, not those who are still living an active life. It might be useful to outline some of the features which characterize the group and which have a bearing on the part played by food and catering. 
There is in the first place a slowing down and a narrowing of horizon due to the limiting factors of physical infirmity and financial stringency. Often loss of status, due for the bread-winner to retirement and for the woman to no longer being the pivot of family life, brings in its wake a sense of uselessness, of being unwanted, of no longer being able to contribute. These are general characteristics of ageing; but if there are no compensatory features such as the attentions of the family circle, outside interests, friends and someone with whom to share life, then the burden of loneliness and inadequacy may cause a deterioration which finds relief only in help by the community. This help may be in people's own homes through the domiciliary services, or in residential accommodation.

The old person's reactions to feeding reflect those difficulties in two ways: there is a compensative overeating culminating in an obesity which may be immobilizing through its effect on heart, arthritic joints and bodily movement; or an apathy extending to disinterestedness in food and eating which results in a state of malnutrition recognized medically. In addition, poor feeding may be due, inter alia, to the purely physical obstacles of not being able to go shopping, inadequate cooking facilities, or an inability to make the effort to combat difficult living conditions. Lastly, arthritis or paralysis may so hamper movement as to make preparation and cooking of meals nearly impossible. In these circumstances the only way to enable old people to continue living in their own homes is to provide either a mobile meals service for the house-bound or a centre where meals are provided for those who can get out.

The expansion of the meals-on-wheels service which might be termed group feeding by dispersal has been rapid since it was pioneered by the British Red Cross Society. The Women's Voluntary Service, the organization now providing the largest number of meals, delivers over $1 \frac{1}{4}$ million meals a year through $3^{20}$ separate schemes.

There is no doubt that this service is of considerable value not only on account of the hot meal provided but because the personal contact with the voluntary workers, who in effect become visitors, gives a boost to morale which is reflected in everything else the old person does.

Despite the number of meals being delivered, the service cannot be said to cover the country's needs. Many areas have deliveries only twice a week. The main stumbling blocks to expansion are the high cost of transport and a shortage of voluntary workers over the lunch-hour period when most women are occupied with their own home duties. This is a service for which local authorities have permissive powers to grant aid under section $3 \mathrm{r}$ of the National Assistance Act, I 946, and in many areas grants towards renewing vehicles, meeting mileage costs, and providing equipment could do much. In rural areas the distances to be covered are a further problem.

The average price charged for meals-rs.-is, of course, a subsidized figure, the remainder of the cost being met by the organizing body which is frequently reimbursed by local authority grant. Even so there are a number of old people who make cost an excuse for not having meals more frequently.

The meal supplied is usually of the meat, two vegetables and a sweet variety. Some services are able to offer an alternative of fish, others a soup with a helping of 
mashed potato and a sweet at a reduced cost, and in some areas a milk pudding is always available as an alternative sweet.

The meals are obtained from a variety of sources such as local caterers, industrial canteens, school-meals services, local-government canteens, hospital kitchens and old-people's homes. Daily Clubs providing hot lunches usually also supply the mobile meals round. The British Red Cross Society and the Women's Voluntary Service sometimes undertake their own cooking by voluntary labour or by paying a cook and using other voluntary assistance.

Except in the last instance there is little possibility of choice in the meals provided and old people complain that they are not getting the meals they would like and so cease to take them, which is often an expression of general dissatisfaction with life and may not be the fault of the meals.

Many old people refuse the meal at first because of what the neighbours will think, others genuinely dislike the idea of food in a tin and some have legitimate cause to grumble at the palatability of the meal. Some of the fault here lies with the prohibitive cost of good heat-conservation methods for small services.

In general the services do not supply special diets, the notable exception being the Invalid Kitchens of London, where service to old people though quite extensive is incidental. One County Borough felt that old people might make more use of the service if a light diet was included. However, out of an annual delivery of some 27,000 meals only a few hundreds of the light diet are required.

Eating is essentially a social function and those of us who customarily share our meal time would find it difficult to estimate the effect on appetite of always eating alone. Many active old people do in fact go to a cafeteria or restaurant to gain the pseudo-companionship offered by the chance encounter, and in some areas it is being encouraged by the provision of luncheon vouchers. The scheme is administered by the local old-people welfare committee and financed by the local authority. Other elderly people who need a homely atmosphere and the support of established friendships find the daily club organized by old-people's welfare committees in many areas a great boon.

In some London areas the arrangement is solely for a meals club, the meals being supplied in bulk and the individual served by voluntary labour. A survey of 10,000 meals served in this way in a year in Bermondsey, showed that $60 \%$ were consumed at the centres, $30 \%$ taken away in containers to be eaten at home, and 10\% delivered to the housebound.

Club premises are usually open all day for social activities. Kitchen facilities permit the supply of elevenses, midday meals and teas. A cook caretaker is usually employed and helped by volunteers, often from among the old people themselves. Not merely does this system reduce the overheads but it allows the old people to make a contribution and adds the personal touch which is an important ingredient in its success.

Seating accommodation and kitchen facilities limit the numbers that can be catered for in this way. The average for any one club is 40-I00 midday meals, which 
can often only be achieved by two sittings. The cost of the meal is again tailored by subsidy to suit the pensioner's purse.

An extension of this scheme is the Day Centre for the infirm who are collected by car or ambulance and spend the day in the Centre. A midday meal is provided and in one such centre the old people have submitted to a daily dose of orange juice.

The Day Hospital which is developing as an outpatient extension, particularly of geriatric units, also provides a midday meal which is a function of the hospital's catering service.

Housing projects of local authorities and voluntary societies, of the single-room flatlet variety, are trying in some areas to encourage a communal midday meal among the residents. Cooking would usually be undertaken by the house mother.

It will be seen that the group feeding of old people who are living in their own homes is a responsibility undertaken mainly by the voluntary organizations using part-time voluntary workers.

Residential accommodation provides the inevitable solution for those old people who have no-one to care for them and who can no longer fend for themselves. This provision is now a statutory requirement under the National Assistance Act, and welfare authorities now run over 800 such homes which vary in size from the small home of thirty residents to the large institutional type of over rooo beds housed in old workhouses. Voluntary organizations who had pioneered the small communal home now have more than 600 , some of them caring for as few as sixteen residents, which is not an economic number.

By definition the residents do not require nursing and are not in need of hospital care but in fact many of them are now so infirm that the present system of staffing is overburdened. With night attendants an exception, and with the shortage of staff and the insufficient number of trained people, the demands of night supervision constitute a real problem for both statutory and voluntary organizations.

Almost without exception the matron is solely responsible for the catering arrangements and the nutritional welfare of the residents is dependent on her skill and knowledge. The nutritional advisory service of the Ministry of Health is available but there are no appointments in this field by local authorities or voluntary bodies.

The attitude of the employing agencies is that old people should be given a good varied diet at reasonable cost with no indication as to how to achieve it, the general direction being to provide 'Mum's apple pie'.

Thus the control exercised is budgetary, any advice being confined to principles of management. It is usually given by a visiting administrative officer. The reports of inspection visits by members of committees of management are a supplementary check on the success or otherwise of the matron's housekeeping. Some voluntary bodies and certainly one county body have a home committee based locally, and there spot checking can more readily occur.

Though a free rein for the matron does encourage a human approach to catering, as long as good management is the criterion of good feeding there is the danger that emphasis may be given to low provisions' costs instead of to a balanced diet. Published statistics show that in County Welfare Homes in England the provisions' 
costs per head per week vary from 13 s. to I 4 s. to an exceptional 28 s. in a small home, the average being less than 20 . Though expenditure cannot be the only guide, it is reasonable to entertain doubts as to the adequacy of a diet provided for less than $15 \mathrm{~s}$. per week, particularly in view of the recently published national figure of $27 \mathrm{~s}$. 3 d. One local authority averaging between $15 \mathrm{~s}$. and $\mathrm{r} 6 \mathrm{~s}$. agreed that with this sum they provided only $\frac{1}{2} \mathrm{pt}$. milk a head daily and eggs rarely. This County Welfare Committee feels the provisions estimates are too low and is reviewing them. Professional advice has even been mentioned but with no great enthusiasm. A tentative suggestion in another quarter that the natural course might be to consult the expert already in charge of school meals was coldly received.

Costs in voluntary homes are more difficult to quote as figures are not published. Inquiries indicate that they are rather higher, and when low figures are shown it is usually owing to a disregard of gifts and home produce. One organization with several homes instances 20-25s./week. Another allows the matron to spend 27s./ week. In this Home there is a good balanced diet including fresh fruit, though care has to be exercised over this item. Cooked breakfast is the rule and a protein dish at midday and at 7 p.m. supper. Residents have a pint of milk a day over and above that used in cooking. The matron has had no special training. A local-authority home spending $18 \mathrm{~s}$. $6 \mathrm{~d}$./week, with a state registered nurse for matron, compares very favourably as to diet. This sum does not permit fresh fruit or fruit juices and only $\frac{3}{4}$ pt. fresh milk overall. However, the matron supplements with powdered milk in puddings and soups. In this home high tea is at about 5 p.m.; and a hot drink or soup and biscuits and sometimes sandwiches are available in the evening. A supper meal at 7 p.m. had been tried here but on the evidence of the food wasted the matron thought the old people lost nutritionally and reverted to the high tea.

Another authority whose homes have their high tea at 4 p.m. was also questioned on the time gap between this meal and an $8.30 \mathrm{a} . \mathrm{m}$. breakfast. It was argued here that the old people like to go to bed at 7 p.m. as they started rising any time after 5 a.m. In large homes the staff had to come on duty at this time to have all their prebreakfast duties finished by $8.30 \mathrm{a} . \mathrm{m}$. and with the reduction of working hours to $42 /$ week it was impossible to arrange for a meal later than $4 \mathrm{p} . \mathrm{m}$. This attitude is at variance with the reaction of a voluntary home which is using voluntary helpers to provide evening activities. The effect has been to restore normal hours and meal times to everyone's satisfaction.

The only training which is provided for matrons and wardens of old people's homes is that given in courses organized by the National Old People's Welfare Council. Some matrons have a domestic-science and catering background, others have nursing training, but a great majority have no specialized training and bring only the knowledge and standards of the ordinary housewife to the job.

In planning menus the matron has to contend with the ingrained eating habits of a lifetime and it is often claimed that old people are not re-educable. Certainly few of them associate health with eating and most are satisfied that 'a little of what you fancy does you good'. Their fancies and prejudices pay scant regard to food values. 
The view frequently expressed that as the old people's main interest is food they should not be disturbed in their likes and dislikes is sometimes a cover for doing what is convenient for the staff.

The atmosphere of the home affects the reception of food, and constant grumbling about the catering may be an expression of grievance against the management of the home or indicate a lack of sympathy on the part of the matron rather than reflect truly the quality of the meals. The intensely personal nature of the response to food is a corollary to the loss of possessions and community status which has befallen these old people, and for them food becomes both a symbol and a weapon. This fact presents a temptation to any matron over anxious to please; one I know kills any new dish stone dead by her desire for appreciation.

In old people there is no foreseeable gradation in tastes over a period as there might be in a group of children from say i I to I 5 years of age. Innovation is regarded with suspicion. New ideas must be introduced with care and once established may have to be maintained. These are among the factors rendering planning more difficult.

For women particularly it is sometimes difficult to accept the fact of having no jurisdiction in the kitchen and so the charge of spoiling good food may be levelled and incline the recipients to fussiness. One Home treats this attitude imaginatively by allowing the residents to do a little cooking on cook's day off, which for the more active is a release from the frustration of never doing more than lay the table or help with preparation of fruit and vegetables.

Organized feeding greatly restricts the exercise of choice which some homes do their best to eliminate aitogether, as in one where the milk and tea are put out already mixed giving a service similar to that of a station refreshment bar.

It is important that when the big freedoms are lost, when communal living is further encroaching on individual liberty and the inroads on privacy are almost complete, the small choice should be treasured. In these old people there is not the compensation the majority enjoy of indulging their whims of appetite, of popping into a shop to satisfy a fancy, and choosing becomes a precious prerogative. To hinder its indulgence is the ever present bogey of waste, but the matron who treats this need sympathetically would be well repaid.

Grouping is an invidious principle but a social necessity. The late Margery Fry, herself an admirable example of adjustment to ageing, made a plea that when we are caring for the elderly we should respect their personalities whilst grouping their infirmities, and it is difficult to think of any better attitude in which to approach the problem we have been discussing.

REFERENCE

Drummond, J. C. \& Wilbraham, A. (1957). The Englishman's Food, and ed. London: Jonathan Cape. 